\title{
Anna Czepiel
}

\section{Dobre i złe sposoby obrony wartości rodzinnych - polemika $z$ profesorem Zbigniewem Stawrowskim}

DOI 10.35757/CIV.2015.17.14

Jest dostatkiem mleka, chleba,

Sa owoce $i$ jagody. Mów, czego trzeba dla duszy, Aby się dostać do nieba?

\section{Wprowadzenie}

W artykule osobliwie zatytułowanym Klaps jako imperatyw kategoryczny, profesor Zbigniew Stawrowski dokonuje próby usprawiedliwienia stosowania przez rodziców wobec dzieci lekkich kar fizycznych w kontekście rozszerzenia w ostatnich latach prawnych możliwości ingerencji urzędników państwowych w życie prywatne rodziny, w której zachodzi podejrzenie stosowania przemocy. Pewna zaleta artykułu Zbigniewa Stawrowskiego jest wyrażenie przez autora - jako refleksji towarzyszacych tematowi tytułowemu - ciekawych i nowatorskich rozważań na gruncie filozofii polityki i filozofii moralności, które odnoszą się do szerokiego zagadnienia relacji między rodziną a władzą państwową. Na przykład, nieza-

Anna Czepiel - absolwentka Wydziału Dziennikarstwa i Nauk Politycznych Uniwersytetu Warszawskiego, studiowała także na Uniwersytecie w Genewie, a obecnie przebywa na stypendium na Katolickim Uniwersytecie w Leuven, pisze pracę magisterska w Instytucie Politologii Uniwersytetu Kardynała Stefana Wyszyńskiego w Warszawie. 
leżnie od stwierdzeń autora, jakoby rodzicielskie klapsy miały być „moralnym obowiązkiem” i „symbolicznym wyrazem najgłębszej miłości", na uwage zasługuje następujace istotne dla filozofii polityki stwierdzenie profesora Stawrowskiego: „Zadaniem rodziców jako wychowawców, którzy przygotowuja swe dzieci do samodzielności, musi być również to, by w ramach przenikniętego miłościa procesu wychowania uczyć dzieci elementarnego poczucia sprawiedliwości, niezbędnego do życia w państwie”. Rodzice nie moga więc zapominać o tym, że dziecko wychowywane jest w konkretnej wspólnocie politycznej: jednym $z$ ich zadań jest przekazywanie wiedzy na temat obowiąujacych w państwie praw i obowiąków. Kolejnym takim wartym uwagi poglądem jest podkreślenie przez autora na podstawie filozofii Immanuela Kanta, że państwo, jako byt służebny wobec człowieka, powinno chronić nie tylko między innymi własność prywatna obywatela, ale także obejmujace go relacje międzyludzkie, np. rodzinne. Odnosząc się do głównego tematu artykułu, warto podkreślić, że mimo tytułu sugerującego radykalizm w tej kwestii, tekst nie okazuje się pochwała stosowania lekkich kar cielesnych jako głównego, używanego $z$ dużą częstotliwościa środka wychowawczego. Profesor Stawrowski kilkakrotnie podkreśla, że mimo iż jego artykuł ma na celu obronę możliwości stosowania takich kar przez rodziców, omawiana kara fizyczna powinna być metoda stosowana tylko w wyjątkowych sytuacjach, „zajmujacca - jak pisze autor - skrajne miejsce na szerokiej palecie środków wychowawczych". Zbigniew Stawrowski słusznie potępia przypadki znęcania się nad dziećmi, dostrzegając przy tym także zjawisko przemocy psychicznej wobec dziecka, podczas gdy bywa ono przez wielu konserwatywnych myślicieli i publicystów niesłusznie krytykowane jako pewien wymysł i przesada. Ponadto, mimo dokonywania, na gruncie filozofii politycznej i moralnej, pochwały stosowania $\mathrm{w}$ niektórych przypadkach lekkich kar cielesnych wobec dzieci, autor podkreśla wartość podmiotowości i autonomii dziecka: sprzeciwia się twierdzeniu, że „dziecko - niczym jakiś przedmiot - jest własnością swoich rodziców”, a krytyko- 
wane przez siebie „bezstresowe wychowanie”, którego elementem jest odrzucenie stosowania klapsów, Stawrowski nazywa jedynie "dalekim echem" wyrażanego między innymi przez Jana Jakuba Rousseau postulatu, aby „dzieciom pozwolić być soba, nie ingerować w ich swobodę, aby mogły bez przeszkód wyrażać naturalne skłonności i rozwijać swoje osobiste predyspozycje".

$\mathrm{Na}$ tym jednak kończą się zalety omawianego tutaj artykułu profesora Zbigniewa Stawrowskiego - skądiną, co trzeba $z$ ogromnym szacunkiem podkreślić, autora wielu wybitnych tekstów poświęconych zagadnieniu wspólnoty politycznej oraz jakości debaty publicznej, takich jak Prześwit dziejów (2010) czy Aksjologiczne podstawy konstytucji (2007). Do artykułu Klaps jako imperatyw kategoryczny można mieć wiele zastrzeżeń, które w niniejszej polemice zostały podzielone na trzy główne kategorie. Po pierwsze, krytycznie należy spojrzeć na próby „uszlachetniania” - w rzeczywistości stosowanego najczęściej w zdenerwowaniu i w innych emocjach - rodzicielskiego klapsa jako rzekomo $z$ natury swojej „moralnego obowiązku”, wyrazu opiekuńczej miłości, poprzedzonego głębokim przekonaniem rodzica, że właśnie taką karę należy zastosować. Po drugie, argumentacji profesora Stawrowskiego można zarzucić wybiórcze odnoszenie się do filozofii Immanuela Kanta w uzasadnianiu moralnego charakteru rodzicielskich klapsów. Autor zdaje się nie zauważać, że przytaczane przez niego kluczowe tezy filozofii Immanuela Kanta, wobec których formuła imperatywu kategorycznego jest tylko pochodna, same w sobie zaprzeczaja pochwale stosowania klapsów jako moralnego obowiąku rodziców (chodzi o takie wymieniane przez Stawrowskiego założenia filozofii Kanta jak na przykład koncepcja człowieka jako celu samego w sobie oraz posiadanie przez człowieka niepodważalnych praw, w tym nienaruszalności cielesnej). Zbigniew Stawrowski pomija również istotna dla poruszania tematyki tak zwanych klapsów kwestię potępienia przez Kanta czynów ośmieszających drugiego człowieka. Po trzecie, w kontekście - mającego uzasadniać stosowanie rodzicielskich klapsów - stwierdzenia autora, 
że wychowanie ma być „uczeniem zasad, które obowiązuja ludzi w ich wzajemnych relacjach", daleko niewłaściwe jest dokonywanie przez niego szczególnej pochwały właśnie tak zwanego klapsa, a nie innych kar rodzicielskich, odwzorowujących te, które obowiazuja $\mathrm{w}$ typowych dla swiata dorosłych interakcjach, takich jak relacja pracodawca-pracownik (na przykład zakazanie dziecku oglądania telewizji jako odpowiednik obniżki wynagrodzenia w świecie pracujacych dorosłych).

\section{Przeciw "uszlachetnianiu" rodzicielskiego klapsa}

Należy zgodzić się $z$ profesorem Zbigniewem Stawrowskim, że rodzicielski klaps, jako kara niezagrażajacca życiu dziecka, nie powinien powodować reakcji funkcjonariuszy państwowych, prowadzącej do pouczenia rodziców czy też nawet do odebrania dziecka $z$ domu i przekazania go $\mathrm{w}$ ręce opiekunów zastępczych. Absurdem i czymśs wysoce niestosownym w państwie prawa byłoby także, $\mathrm{w}$ wyniku potencjalnego powstania w społeczeństwie atmosfery absolutnego sprzeciwu wobec wymierzania dzieciom lekkich kar fizycznych, swoiste inwigilowanie rodzin przez sąsiadów czy wręcz przez różne urzędy w celu sprawdzenia, czy taka kara przypadkiem nie jest wobec dziecka stosowana. Do takich sytuacji dochodzi już teraz w krajach skandynawskich.

Zbigniew Stawrowski nie zatrzymuje się jednak na słusznym wskazaniu na absurdalność i niemoralny charakter możliwości karania rodziców przez instytucje państwowe za relatywnie rzadkie stosowanie wobec dziecka tak zwanego klapsa, lecz idzie jeszcze dalej: podkreśla, że rodzicielski klaps jest „obowiąkiem moralnym” rodzica oraz "symbolicznym wyrazem najgłębszej miłości i najlepiej pojętego odpowiedzialnego wychowania w sytuacjach najtrudniejszych wychowawczo". 
Warto zauważyć, że „obowiązek moralny” nie jest tu żadna poetycka metafora czy skrótem myślowym. Według Stawrowskiego, przekonanie o konieczności wymierzenia podopiecznemu klapsa rodzice nabieraja w sposób opisywany przez Immanuela Kanta w formule imperatywu kategorycznego, a następnie - jeżeli chca postapić moralnie - decyduja o zastosowaniu takiej kary. Jak pisze Stawrowski: „Kant wskazuje na pewne elementarne doświadczenie źródłowe, które polega na tym, że w pewnej sytuacji pojawia się w nas świadomość bezwzględnego zobowiązania - pewność, "że absolutnie powinno się postapić w pewien sposób. (...) Świadomość tego podstawowego prawa można nazwać faktem rozumu". (...) Wraz z doświadczeniem takiego obowiązku odsłania się przede nami jakieś konkretne ewidentne dobro - dobro w ścisłym sensie moralne, które domaga się zrealizowania, oraz jego druga strona - moralne zło, kiedy nie dopełnimy naszego obowiazku”. Przykład ten, jak zresztą wiele innych możliwych do wyobrażenia sobie przypadków stosowania imperatywu kategorycznego, mogących dotyczyć zupełnie odmiennych działań, takich jak okazywanie pozytywnych, ciepłych uczuć, jest oczywiście formalnie poprawny - nie ma przeszkód, aby rzeczywiście zaistniała sytuacja, w której rodzic subiektywnie nabiera głębokiego przekonania, że moralnie słuszna kara wobec dziecka jest w danej sytuacji wyłącznie zastosowanie lekkiej kary fizycznej.

Warto jednak zwrócić uwage na dwie - bardzo ściśle ze soba w tekście splecione - zastanawiające cechy artykułu Zbigniewa Stawrowskiego, które sprawiaja, że argumentacja autora może prowadzić do „uszlachetnienia” wszystkich przypadków wymierzenia dziecku lekkiej kary cielesnej, także wtedy, kiedy tak zwany klaps jest stosowany wcale nie w wyniku świadomości obowią$\mathrm{ku}$ moralnego, ale $z$ powodu zwykłego zdenerwowania, desperacji czy też lenistwa rozumianego jako niechęć do wymyślenia lepszego, bardziej adekwatnego w danej sytuacji sposobu na zdyscyplinowanie dziecka. Po pierwsze, formuła imperatywu kategorycznego została przez Zbigniewa Stawrowskiego znacznie uproszczona. 
Po drugie, mimo że autor kilkakrotnie wskazuje, że rodzicielski klaps powinien być środkiem stosowanym sporadycznie, w innych fragmentach artykułu traktuje tak zwanego klapsa jako karę, która ze swojej natury jest realizacja przez rodziców ich moralnego obowiazku oraz stanowi wyraz ich miłości do dziecka.

$\mathrm{Na}$ czym polega to widoczne w omawianym tekście uproszczenie Kantowskiego imperatywu kategorycznego? Zgodnie $z$ zastosowanym przez Zbigniewa Stawrowskiego opisem tego pojęcia wystarczy, że człowiek poczuje pewien impuls, który mówi mu: „tak trzeba postąpić!”, a już staje się on głosem moralnego prawa. Nieuczciwościa byłoby jednak pominięcie faktu, że autor doradza w takiej sytuacji głębszą refleksję, wskazując na konieczność uświadomienia sobie, czy planowany czyn jest obowiazkiem moralnym, poprzez posłużenie się Kantowskimi definicjami: „Postępuj tylko według takiej maksymy, dzięki której możesz zarazem chcieć, żeby stała się powszechnym prawem” oraz „Postępuj tak, byś człowieczeństwa tak w twej osobie, jako też w osobie każdego innego, używał zawsze zarazem jako celu, nigdy tylko jako środka”. Jednak u Stawrowskiego skorzystanie $z$ tych definicji ma mieć charakter jedynie pomocniczy, nieobligatoryjny. Nieistotność roli, jaka, według Stawrowskiego, przy stosowaniu rodzicielskiego klapsa miałaby odgrywać rozwaga, doskonale ukazuja właśnie te fragmenty artykułu, w których autor automatycznie - świadomie lub nie - definiuje każdego rodzicielskiego klapsa jako czyn szlachetny moralnie i wypływający $z$ miłości rodzicielskiej. Stawrowski pisze: 1. „Odpowiedzialni i normalnie myślący rodzice dobrze wiedza, że klaps nie jest żadnym biciem, nie jest nawet czymś szkodliwym, lecz - przeciwnie - jest czynem o wysokiej wartości wychowawczej i dlatego zasługuje wręcz na pochwałę"; 2. „O tym, jaki klaps jest w danym momencie odpowiedni, moga rozstrzygnąć jedynie sami rodzice. Nikt inny ich w tym nie zastapi, bo nikt inny nie kieruje się wobec dziecka taka miłością, nie zna go tak dobrze, jak rodzice, nie potrafi ocenić konkretnej sytuacji w całym jej złożonym, dynamicznym, istotnym dla właściwego wychowawczego 
podejścia długookresowym kontekście” (kilka zdań później autor nie pozostawia jednak złudzeń, że tak naprawdę na to „rozstrzyganie” rodzic nie ma czasu, ponieważ konieczność zastosowania klapsów jest charakterystyczna dla „sytuacji wymagających zdecydowanych, nadzwyczajnych reakcji”); 3. „Przestrzeń rodzicielska jest przestrzenią miłości”; 4. „Dopóki nie ma oczywistych dowodów, że rodzice w stosunku do dzieci nie kieruja się odpowiedzialna miłością, kwestionowanie ich wysiłków pedagogicznych i stosowanych przez nich środków wychowawczych (...) jest bezzasadne". We fragmentach tych widać bezkrytyczna ufność autora w rygoryzm moralny rodziców i w ich nieomylność. Zdania te daja do zrozumienia, że rodzicielski klaps jest rzekomo zawsze, czy też w większości przypadków, realizacją moralnego obowiązku i troskliwej miłości do dziecka, bez względu na takie kwestie jak: częstotliwość wymierzania tej kary (codziennie czy może tylko w wyjątkowych sytuacjach), dojrzałość psychiczna rodziców, możliwość stosowania omawianej kary pod wpływem emocji, a nie rozwagi moralnej, a także prawdopodobieństwo wymierzenia dziecku tej kary niesłusznie (na przxykład w wyniku zarzucenia dziecku zniszczenia jakiejś rzeczy, którego w rzeczywistości dokonał ktoś inny).

Tymczasem, do czego Zbigniew Stawrowski już się nie odnosi, Immanuel Kant jasno wskazuje na konieczność odrzucenia emocji i chłodnego rozważenia, czy dana myśl jest głosem prawa moralnego. Jak bowiem zauważa filozof $z$ Królewca, emocje i biologiczne skłonności zawsze utrudniają człowiekowi postapienie zgodnie $z$ prawem moralnym: „Prawo [moralne] narzuca się [człowiekowi] ciągle $\mathrm{w}$ nieodparty sposób na mocy tkwiącej w człowieku moralnej predyspozycji. (...) Jednak w sposób przez siebie niezawiniony, wskutek swojej równie naturalnej predyspozycji, [człowiek] jest przywiąany także do pobudek zmysłowych"1. Na konieczność chłodnej analizy impulsu, który może - lecz nie musi - mieć charakteru wezwania prawa moralnego, jeszcze bardziej

1 I. Kant, Religia $w$ obrębie samego rozumu, w: idem, Dzieła zebrane, t. V, przekład A. Bobko, Wydawnictwo Naukowe Uniwersytetu Mikołaja Kopernika, Torun 2011, s. 38. 
dobitnie wskazuje inny cytat $z$ Kantowskiej Religii $w$ obrębie samego rozumu: „Nawet najbardziej ograniczony człowiek jest zdolny do odczucia tym większego szacunku dla postępowania zgodnego $z$ obowiązkiem, im bardziej odłącza od niego w myśli inne pobudki, które przez miłość własna mogłyby mieć wpływ na maksymę postępowania"2.

Można wyobrazić sobie, że niektórzy rodzice czy opiekunowie podejmuja $\mathrm{w}$ sytuacji konieczności zdyscyplinowania dziecka tego rodzaju chłodna pracę myślowa, w wyniku której szczerze uznaja, że obowiazkiem moralnym jest taki, a nie inny sposób ukarania dziecka. Przypadki takich „filozofujących” rodziców należą jednak zapewne do rzadkości. W swoim tekście profesor Zbigniew Stawrowski często odwołuje się do przykładów $z$ życia codziennego oraz do zdrowego rozsądku, „normalnego myślenia”. Stosując podobne odwołanie, można $z$ absolutna pewnością stwierdzić, że zdrowy rozsądek, a także znajomość - w tym w charakterze obserwatora zdarzenia - codziennych sytuacji zwiazanych $z$ wymierzaniem dzieciom kar prowadzi do prostego wniosku, że stosowanie rodzicielskich klapsów jest prawie zawsze wynikiem zdenerwowania, desperacji bądź też innych emocji, a decyzja o ukaraniu dziecka $\mathrm{w}$ ten sposób jest podejmowana pod wpływem chwili, bez nawet kilkunastu sekund rozwagi. Klaps ma charakter raczej „utylitarny”, ponieważ ma prowadzić, bez czasochłonnego wyjaśniania, do szybkiego zdyscyplinowania krnabrnego dziecka, aby rodzic zyskał spokój. Uproszczona przez Zbigniewa Stawrowskiego formuła imperatywu kategorycznego, polegajaca na sprowadzeniu tego prawa do pozbawionego rozwagi impulsu „tak trzeba!”, $\mathrm{w}$ połączeniu $\mathrm{z}$ zawarta $\mathrm{w}$ omawianym artykule idealizacja motywów rodziców wymierzajacych tak zwane klapsy, może prowadzić do niebezpiecznego „uszlachetniania” - jako rzekomo „moralnie uprawnionych" i będących „wyrazem najgłębszej miłości” - tych rodzicielskich klapsów, które wynikaja $z$ prostego ludzkiego zdenerwowania, dążenia do zyskania spokoju czy też ze spowodowa-

2 Ibidem, s. 50. 
nej na przykład problemami zawodowymi frustracji prowadzącej do nadmiernej chęci zademonstrowania władzy rodzicielskiej. A takie sa właśnie przyczyny znacznej większości przypadków wymierzenia dzieciom tak zwanych klapsów.

Warto zauważyć, że taka argumentacja Stawrowskiego może prowadzić do obrony status quo, czyli częstego w Polsce zwyczaju karania dzieci tak zwanym klapsem za drobne przewinienia (na przykład potknięcie się na ulicy, stłuczenie szklanki), za które dorosłych nie spotykają żadne kary, a jedynie ludzkie współczucie czy pomoc. Ten polski zwyczaj potwierdzaja wyniki badań psychologicznych, na przykład przeprowadzonych w 1998 roku na grupie 250 dzieci w wieku 12 lat: „12\% dzieci przyznało, że ich rodzice stosuja kary fizyczne powszechnie (nawet za drobne przewinienia), zaś ponad $30 \%$ podało, że zna co najmniej jedno dziecko, które było ciężko pobite przez rodziców lub też takie, które bite jest nawet za błahe przewinienia" ${ }^{\text {. }}$

$\mathrm{Na}$ koniec tej części polemiki warto odnieść się właśnie do stwierdzenia Zbigniewa Stawrowskiego, jakoby rodzicielski klaps był „wyrazem najgłębszej miłości” opiekunów do dziecka. Rozważanie, czy dany czyn można nazwać płynącym z „troskliwej” i „najgłębszej” miłości, trzeba określić jako coś, co czyni - i tak już wymagające rzetelności i czasu - zastanawianie się nad moralnościa czynu jeszcze poważniejszym procesem myślowym. Dlatego, pomijając pewien niesmak stylistyczny, jaki niesie określenie rodzicielskiego klapsa „wyrazem miłości”, warto podkreślić, że epitet „wyraz najgłębszej miłości” należy pozostawić dla czynów o dużo bardziej znaczącym, wręcz heroicznym charakterze, takim jak decyzja rodzica o przeznaczeniu choremu dziecku swojego narządu do transplantacji, rezygnacja ciężarnej kobiety, której życie jest zagrożone, $z$ leczenia mogącego prowadzić do śmierci nienarodzonego dziecka, czy té̇ nawet niezwiązane $z$ zagrożeniem

3 A. Piekarska, Przemoc, kary cielesne i krzywdzenie dzieci, „Dziecko Krzywdzone. Teoria, badania, praktyka" 2003, nr 3, s. 5, http://www.ipsir.uw.edu.pl/UserFiles/File/Katedra Socjologii_Norm/TEKSTY/PiekarskaKrzywdzenieDzieci.pdf [dostęp: 21 marca 2016]. 
życia decyzje, takie jak przeznaczenie przez bardzo uboga rodzinę pieniędzy na zajęcia dodatkowe dziecka, aby mogło ono rozwijać pasję sportowa czy artystyczna.

\section{Rodzicielski klaps \\ jako czyn przeczący podstawowym założeniom filozofii Immanuela Kanta}

Rozważania Zbigniewa Stawrowskiego sa oparte na podkreślaniu, że klaps wymierzany dziecku przez rodziców jest kara szczególna. Warto zapytać, co takiego charakteryzuje ją w porównaniu $z$ innymi sposobami dyscyplinowania dziecka. Autor podkreśla, że rodzicielski klaps nie jest „zadawaniem bólu” podopiecznemu czy tė̇ „agresją i znęcaniem się" nad dzieckiem. Można się zgodzić, że bolesność tej kary zazwyczaj nie jest duża i trwała. Profesor Stawrowski szczególny charakter rodzicielskiego klapsa widzi za to w jego symbolice: „Jest on dla dziecka prostym, jednoznacznym i następującym bezpośrednio po wykroczeniu sygnałem, że pewnych rzeczy w żadnym wypadku robić nie wolno". Skoro ból nie jest głównym celem rodzicielskiego klapsa, jest nim $\mathrm{w}$ takim razie - co pokazuja przytoczone słowa autora - sam fakt, że kara została wykonana, że dziecko po jakimś uczynku zostało uderzone we wrażliwą, wręcz intymna część ciała. Stąd blisko do stwierdzenia, że tą szczególną funkcją klapsa, także w postaci samej groźby wymierzenia tej kary, jest pewne ośmieszenie dziecka. Ta cecha omawianej kary ma gwarantować, że w obawie przed tym ośmieszeniem dziecko nie będzie już popełniać zabronionych przez rodziców czynów.

Nawet jeżeli stwierdzenie o ośmieszeniu jako celu omawianej kary cielesnej nie kryje się intencjonalnie za słowami profesora Stawrowskiego, czymś oczywistym jest, że ukaranie człowieka niezależnie, czy dorosłego, czy dziecka - poprzez uderzenie wymierzone w intymną część ciała jest czynem ośmieszającym. Szczegól- 
nie jeżeli stosowane bywa publicznie, tak jak sugerowane to jest w opisywanym przez Zbigniewa Stawrowskiego przypadku wymierzenia rodzicielskiego klapsa dziecku, które na placu zabaw bije łopatka w piaskownicy swojego rówieśnika. Ważność traci tu często używana w argumentacji Stawrowskiego metafora klapsa jako pouczającego odpowiednika kary, która zostałaby zastosowana przez aparat państwowy wobec dorosłego popełniajacego wykroczenie czy przestępstwo. W zachodnioeuropejskiej kulturze instytucje państwowe stosuja bowiem kary pozbawione przemocy fizycznej, których charakter - mimo ich dotkliwości - nie ośmiesza czy też nie zawstydza ukaranego (można tu wymienić mandaty, prace społeczne, areszt, więzienie czy pozbawienie praw obywatelskich).

Oprócz publicznego poniżenia, nawet gdyby świadek miał być tylko jeden, druga ośmieszającą dziecko cechą tak zwanego klapsa jest pewien mechaniczny charakter tej kary, który można również nazwać - sprzecznym zreszta $z$ fundamentami filozofii Kanta - przedmiotowym traktowaniem człowieka: oto rodzic, gdy ma dość jakiegoś zachowania dziecka, chwyta je i wymierza klapsa, po czym dziecko - zgodnie $z$ zasada warunkowania stosowana podczas tresury zwierzat - zazwyczaj przestaje popełniać nieadekwatny $z$ punktu widzenia rodzica czyn. Przywodzi to na myśl traktowanie dziecka jak jakiegoś urządzenia, w którym włącza się i wyłącza określona funkcję. Mocniejszą metafora, uwypuklająca to przedmiotowe traktowanie, jest określenie rodzicielskiego klapsa jako postepowania wobec zepsutego mechanicznego przedmiotu, na przykład ciagle grającej zabawki czy pozytywki, której nie da się uciszyć inaczej niż poprzez agresywne postapienie $z$ tym przedmiotem, na przykład uderzenie nim o ścianę.

Ośmieszanie jest tymczasem stanowczo potępiane w filozofii Immanuela Kanta jako czyn przeczący ludzkiej godności i koncepcji człowieka jako celu samego w sobie, o których wspomina także Zbigniew Stawrowski. Teoria cnót Immanuela Kanta jednoznacznie wymienia ośmieszanie jako jeden $z$ trzech „występków naruszających obowiazek szacunku dla innych ludzi”: „Nieokiełznana żądza 
ganienia (...) to pewnego rodzaju złośliwość. (...) Ma w sobie coś z radości diabelskiej i przez to stanowi tym cięższe naruszenie obowiązku szacunku wobec innych ludzi" ${ }^{4}$ - pisze Kant o ośmieszaniu.

Zakaz ośmieszania wynika $z$ jednego $z$ kluczowych założeń filozofii Kanta, czyli z niepodważalnej godności człowieka. Warto więc poruszyć problem relacji pomiędzy zagadnieniem rodzicielskich klapsów a filozofia Immanuela Kanta w wymiarze bardziej ogólnym. Wymienione przez Zbigniewa Stawrowskiego fundamentalne cechy filozofii Kanta, które skądinąd słusznie uzasadniają ochronę prywatności rodziny - czyli wskazanie na nadrzędność osoby ludzkiej oraz wypływajaca $z$ niej godność człowieka i jego nienaruszalne prawa - już same w sobie bardziej usprawiedliwiają unikanie stosowania klapsów wobec dziecka niż dopuszczenie moralnego obowiązku wymierzania takiej kary. Szczegółowa egzemplifikacja jest tutaj, po pierwsze, wspomniane Kantowskie potępienie ośmieszania jako czynu naruszającego godność człowieka. Po drugie, oczywistością wydaje się tutaj - przywoływana zreszta przez Stawrowskiego w innym kontekście - zasada nienaruszalności cielesnej. Po trzecie, następujace stwierdzenie Immanuela Kanta, wskazujące na dziecięca zdolność zastanawiania się nad swoimi uczynkami - „Nawet dzieci zdolne sa do odnalezienia najmniejszego śladu domieszki nieprawidłowych pobudek, bo postępowanie traci przy nich momentalnie wszelka moralną wartość" - skłania raczej do potępienia rodzicielskiego klapsa jako kary, która - wbrew słowom Stawrowskiego - mniej „daje do myślenia”, a bardziej jest pewnym rodzajem tresury dziecka, ponieważ metoda ta w dużo mniejszym stopniu pomaga dziecku zrozumieć logikę konsekwencji jego czynów (można porównać sytuację, kiedy dziecko dostaje klapsa za oszukanie rodziców, że umyło zęby, $z$ przypadkiem, kiedy kara za ten sam czyn jest zakaz jedzenia niezdrowych dla zębów słodyczy przez następny dzień). Dziecko

4 I. Kant, Metafizyka moralności, w: idem, Dzieła zebrane, t. V, przekład W. Galewicz, Wydawnictwo Naukowe Uniwersytetu Mikołaja Kopernika, Torun 2011, s. 593.

5 Idem, Religia $w$ obrębie..., s. 50. 
„wytresowane” za pomoca klapsów ma zatem mniejsza możliwość rozwinięcia w sobie takiej wrażliwości, która w dorosłości pozwoliłaby mu samodzielnie - co jest założeniem Kantowskiej filozofii - rozważać moralność swych czynów; większe jest za to prawdopodobieństwo, że osoba taka będzie zastępowała swoje wewnętrzne rozważania moralne bezkrytycznym dostosowywaniem się do nakazów i zakazów $z$ zewnatrz. Nie będzie zatem umiała zbuntować się przeciwko różnym absurdalnym i ograniczającym wolność przepisom państwowym. Społeczeństwo, w którym przeważałyby takie zewnattrzsterowne osoby, ułatwiłoby politykom stworzenie państwa autorytarnego czy też wprowadzenie w życie maksymalnie utylitarnych, ignorujących ludzką zdolność do krytycznego myślenia, koncepcji $\mathrm{w}$ dziedzinie między innymi edukacji (takich jak likwidacja humanistycznych kierunków studiów) ${ }^{6}$.

Tymczasem profesor Stawrowski, po przywołaniu wspomnianych fundamentów filozofii Immanuela Kanta, automatycznie przekierowuje ich znaczenie wyłącznie na kontekst praw rodziców. Ta jednostronność jest widoczna zwłaszcza we fragmencie, w którym po przytoczeniu wypływającego $z$ Kantowskiej filozofii pojęcia godności ludzkiej Zbigniew Stawrowski wspomina o zwiąanym $z$ ta godnościa prawie do „nienaruszalności cielesnej każdej osoby”, które $z$ powodzeniem może stanowić między innymi zasadę potępiająca stosowanie wobec dzieci ośmieszających kar. Stawrowski pomija jednak tę kwestię, nie rozwijając tematu nienaruszalności cielesnej, i natychmiast przechodzi do innego aspektu Kantowskiego „nakazu poszanowania słusznych uprawnień każdej osoby”, czyli do obowiązku respektowania przez państwo „pewnych relacji międzyludzkich, w tym przede wszystkim relacji rodzinnych i rodzicielskich", co w następnych zdaniach prowadzi autora do wniosku, że państwo nie powinno zakazywać rodzicom realizacji zgodnie $z$ ich własnymi upodobaniami należącego do nich „słusznego uprawnienia i moralnej powinności”, jakim jest wychowanie swoich

${ }_{6}$ Por. np. Z. Stawrowski, Świat zadowolonych głupców. Rozmawiał M. Płociński, „Rzeczpospolita Plus Minus", 6-7 czerwca 2015, s. 4-7. 
dzieci. Prościej mówiąc: władze publiczne nie powinny zakazywać stosowania rodzicielskich klapsów. Zatem $z$ omawianego tekstu jasno wynika, że centralne dla Kanta pojęcie godności ludzkiej służy Stawrowskiemu wyłącznie jako argument na rzecz obrony rodzicielskiego prawa do stosowania wobec dziecka tak zwanego klapsa jako „słusznego uprawnienia” rodzica, które to uprawnienie ze względu na jego - rodzica - godność musi być szanowane. Fakt, że profesor Stawrowski wspomina krótko o godności człowieka także w kontekście dziecka, nic w tej kwestii nie zmienia.

Warto zauważyć, że uznanie, iż Kantowskie zasady między innymi nienaruszalności cielesnej czy zakazu ośmieszania dotycza także dzieci, nie niesie jednak ze soba postulatu totalitarnej ingerencji państwa $\mathrm{w} \dot{z} y c i e$ rodzin, gdyż na równi $z$ tymi zasadami wydaje się stać słusznie przywoływana przez profesora Stawrowskiego zasada "pochodnej i służebnej” funkcji państwa, które szanuje i pilnuje słusznych uprawnień każdej osoby bez ingerencji w jej życie prywatne. Zatem dokonywane na gruncie skoncentrowanej wokół godności człowieka filozofii Kanta potępienie stosowania rodzicielskich klapsów odnosi się już nie do zasad funkcjonowania państwa, ale wyłącznie do sumienia każdego $z$ rodziców. Potępiajaca czyny, które ośmieszaja człowieka i łamia jego nienaruszalność cielesna, filozofia Immanuela Kanta prowadzi po prostu do stwierdzenia, że stosowanie omawianej kary rodzicielskiej na pewno nie jest obowiązkiem moralnym, lecz wynikiem postępowania według pobudek innych niż prawo moralne, na przykład emocji takich jak zdenerwowanie.

\section{Klapsy a wychowanie dziecka rozumiane jako nauka zasad dotyczących relacji międzyludzkich}

Zbigniew Stawrowski wielokrotnie stosuje w swoim tekście słuszne - można by powiedzieć: piękne - definicje wychowania, ta- 
kie jak: „uczenie zasad, które obowiązują ludzi w ich wzajemnych relacjach” czy „[prowadzenie do] samodzielnego i odpowiedzialnego kierowania swoja wolnościa”. Zdziwienie budzi jednak to, że definicje te sa przez autora przywoływane w celu uzasadnienia stosowania wobec dzieci tak zwanych klapsów. Utożsamienie kary polegającej na uderzeniu dziecka $z$ wychowaniem polegającym między innymi na „uczeniu zasad, które obowiąuja [dorosłych] ludzi w ich wzajemnych relacjach", jest ogromnym nieporozumieniem. Kara za zły uczynek, za złamanie jakichś zasad - obowiąująca $\mathrm{w}$ relacjach przyjacielskich czy pracowniczych - wśród cywilizowanych ludzi nie polega przecież na stosowaniu przemocy fizycznej.

Ską zatem takie stanowisko autora? Jak zostało już wspomniane we wprowadzeniu, Zbigniew Stawrowski przedstawił w swoim tekście ciekawe i wartościowe ujęcie wychowania jako przygotowania do życia w państwie. Autor rozwija jednak to ujęcie, rysując analogię pomiędzy władzą rodzicielska, stosującą usprawiedliwiona przemoc wobec dziecka, a władzą państwową, która wobec pełnoletniego obywatela dysponuje monopolem na legalna przemoc w przypadku popełnienia przez niego czynu zabronionego. Argumentacja broniąca rodzicielskich klapsów obraca się u Stawrowskiego właśnie wokół traktowania rodzicielskich lekkich kar cielesnych jako pouczajacego odpowiednika kary, która spotkałaby człowieka dorosłego ze strony instytucji państwowych. Według autora, klapsy wymierzane przez rodziców maja być w dzieciństwie „subiektywnie dotkliwym” „jasnym sygnałem”, który uczy, jakie czyny byłyby ukarane przez policję czy sądy w dorosłym życiu. Negatywne konsekwencje takiej „tresury”, także dla budowania społeczeństwa złożonego $z$ samodzielnie myślacych obywateli, omawiane były w poprzednim podrozdziale. Co ważniejsze dla podejmowanego w tej części polemiki problemu Zbigniew Stawrowski, skupiając się $\mathrm{w}$ swoim artykule na przedstawieniu władzy rodzicielskiej i stosowanych przez nia metod wyłacznie jako metafory działania władzy państwowej, zupełnie pomija fakt, 
że życie człowieka dorosłego składa się przede wszystkim $z$ interakcji pozbawionych elementu kontaktów $z$ władza publiczną (na przykład $z$ relacji pracowniczych, koleżeńskich czy rodzinnych). Tymczasem oczywiste jest, że przeważająca część codziennego życia człowieka dorosłego zajmuje nie drżenie przed państwowa kara, tylko relacje $z$ pracodawca, przyjaciółmi i ze znajomymi oraz interakcje $z$ osobami przypadkowymi (jak na przykład sprzedawcy w sklepie). Ze względu na fundamentalny i przeważajacy charakter właśnie takich relacji wychowanie powinno opierać się przede wszystkim na uczeniu dziecka zasad kulturalnych i przyjaznych relacji z innymi ludźmi (na przykład uczciwości, życzliwości, dotrzymywania słowa, poszanowania własności prywatnej), a nie na daleko metaforycznym i niedoskonałym odwzorowywaniu zasad działania aparatu państwowego.

Fakt, że w życiu dorosłego przeważaja relacje pracownicze i koleżeńskie, a nie bezpośrednie ryzyko kontaktu z karząca ręką władzy państwowej, niesie zupełnie inną wizję dyscyplinowania dzieci niż ta, która została zaprezentowana przez profesora Stawrowskiego. Dorosły człowiek, który zostanie oszukany czy obrażony przez swojego kolegę, raczej będzie niechętny do utrzymywania $z$ nim dalszych kontaktów i będzie domagał się naprawienia wyrządzonej mu krzywdy. Pracodawca, widzac lenistwo pracownika, obniży mu wynagrodzenie albo po prostu zwolni go $z$ pracy. W obu tych częstych dla swiata dorosłych negatywnych sytuacjach kara jest - przynajmniej wśród ludzi kulturalnych - inna niż przemoc fizyczna i relatywnie rzadko dochodzi do rozwiazywania konfliktu poprzez angażowanie władz państwowych, takich jak sądy czy policja. Dlatego też sposób karania dziecka powinien bardziej odwzorowywać konsekwencje czynów ponoszonych przez osoby dorosłe, które łamia zasady relacji międzyludzkich. Zamiast pochwały tak zwanego klapsa należy więc pochwalać takie kary jak zakaz wychodzenia na podwórko, jedzenia słodyczy czy korzystania $z$ komputera, ponieważ sa to odpowiedniki konsekwencji złych uczynków ponoszonych przez dorosłych $\mathrm{w}$ typowych relacjach międzyludz- 
kich - obniżenie wynagrodzenia, utrata znajomych na skutek na przykład skłonności do kłamstwa, zablokowanie telefonu w konsekwencji niepłacenia abonamentu. (Na marginesie warto zauważyć, że taka kara jak zakazanie dziecku korzystania $z$ internetu może być dużo skuteczniejsza niż wychwalany przez profesora Stawrowskiego rodzicielski klaps).

Można jednak spróbować zrozumieć pochwałę rodzicielskiego klapsa, która głosi profesor Stawrowski, w kontekście postulowanej przez autora sporadyczności tej kary. Może klaps ma po prostu być odpowiednikiem takich rozwiązań jak wezwanie policji czy pozew sądowy, które są stosowane w świecie dorosłych w najbardziej dramatycznych sytuacjach, kiedy nie pomagaja polubowne próby rozwiąania konfliktu? Jednak, jak zostało już wspomniane, w cywilizowanych krajach, do których należy Polska, kary za przestępstwa i wykroczenia nie sa oparte na przemocy fizycznej - czy to będzie pozbawienie wolności, grzywna, czy też zawieszenie praw publicznych. Owszem, policja i inne służby stosuja przemoc fizyczna, ale przede wszystkim wobec przestępców stawiających opór, przyłapanych na gorącym uczynku. Zatem nawet gdyby pozostać przy przedstawianym przez Stawrowskiego rozumieniu władzy rodzicielskiej jako tej, której nadrzędna rola jest uczenie respektu dla władzy państwowej, analogia między rodzicielskim klapsem „dzisiaj” a państwowa przemoca ,jutro” jest nietrafiona. Wizja wychowania oparta na idei odwzorowywania władzy państwowej, dysponująca jednocześnie karami ośmieszającymi i nielogicznymi z punktu widzenia konsekwencji czynów, pasuje bardziej do przygotowywania do dorosłego życia w państwie totalitarnym, w którym każdy ruch człowieka jest obserwowany przez kamery, obywatel musi być posłuszny absurdalnym zasadom, a państwo rzeczywiście stosuje kary mogące być odpowiednikiem rodzicielskich klapsów, takie jak chłosta, kamieniowanie czy obozy pracy, w których strażnicy stosuja przemoc. 


\section{Zakończenie}

Do powyższych zastrzeżeń głównych można dodać także kilka pomniejszych uwag, na przykład sugerowanie przez autora na początku artykułu, że przeciwnicy wymierzania dzieciom rodzicielskich klapsów wyrażają takie poglądy albo $z$ powodu bezrefleksyjnego cytowania jakiejś „czułostkowo humanitarnej” czy „utylitarno-etatystycznej” ideologii (osoby prywatne), albo też $z$ przesłanek oportunistycznych bądź $z$ chęci podkreślenia posiadanej władzy (politycy). Zapewne takie przypadki się zdarzaja. Jednak przyczyna sprzeciwiania się tej karze, zarówno przez osoby prywatne, jak i polityków, w tym posłów głosujących za konkretnymi ustawami, może być również głębokie subiektywne przekonanie o nieadekwatności tej kary, zarówno w wymiarze psychologicznym, jak i czysto praktycznym (inne niż tak zwany klaps kary rodzicielskie dana osoba może postrzegać jako skuteczniejsze). Kolejna niedoskonałościa omawianego artykułu jest uboga argumentacja we fragmentach majacych uzasadniać skuteczność rodzicielskiego klapsa oraz różnice pomiędzy tą a innymi karami stosowanymi wobec dzieci, podczas gdy szersze argumenty, oparte między innymi na dorobku nauk psychologicznych, wydaja się niezbędne przy poruszaniu tego rodzaju tematów. Ponadto nazywanie rodzicielskiego klapsa „wyrazem najgłębszej miłości” czy też „symbolem” władzy rodzicielskiej sprawia, że omawiany artykuł jawi się jako coś, co - przy całym szacunku dla autora - może budzić zdziwienie czytelników, zamiast prowokować ich do myślenia na temat fundamentalnego zagadnienia, jakim jest relacja państwo-rodzina.

Wreszcie należy zadać pytanie o istotność, jaką artykuł stanowiący pochwałę rodzicielskich klapsów wnosi zarówno do filozofii polityki, jak i do rozważań o rodzinie w innych obszarach nauki. Sprzeciw budzi czynienie przez profesora Stawrowskiego z klapsów - jak pisze sam autor - „symbolu” władzy rodzicielskiej, którego obrona przed zakusami etatystów jest kluczowa dla zapewnienia zdrowego funkcjonowania rodzin. Obrona rodziny przed niesprzyja- 
jacymi uwarunkowaniami prawnymi czy ekonomicznymi jest oczywiście celem bardzo słusznym i szlachetnym. Istnieje jednak wiele ważniejszych kwestii, na które w ramach obrony wartości rodzinnych mogliby zwrócić uwagę konserwatywni myśliciele, w tym Zbigniew Stawrowski. Prawdziwym, a na pewno dużo większym niż możliwość fizycznego karania dzieci, symbolem rodzicielstwa wydaje się między innymi prawo rodziny do spędzania czasu ze sobą. W tym kontekście ogromnym zagrożeniem dla rodziny jest w polskich warunkach ekonomicznych konieczność długiego przebywania $\mathrm{w}$ pracy $^{7}$, aby zarobić na utrzymanie gospodarstwa domowego (w tym często na spłatę kredytu mieszkaniowego), przez co rodzice nie moga poświęcać wystarczająco dużo czasu swoim dzieciom. Problemy mieszkaniowe polskich rodzin, będące ewenementem na tle innych państw Europy ${ }^{8}$, są tematem godnym rozważań nie tylko na gruncie ekonomii i socjologii, ale także filozofii polityki. Innym ważnym problemem jest fenomen rezygnowania przez coraz większa liczbę młodych osób $z$ założenia rodziny na rzecz całkowitego poświęcenia się karierze zawodowej i/lub konsumpcyjnemu stylowi życia. W obliczu tych problemów poświęcanie całego artykułu naukowego usprawiedliwianiu stosowania rodzicielskich klapsów jest czymś przesadnym oraz przesłania prawdziwie naglące i zagrażające rodzinie problemy społeczno-ekonomiczne.

\footnotetext{
7 OECD (Organizacja Współpracy Gospodarczej i Rozwoju) wskazuje na to, że statystyczny Polak przepracowuje aż 1923 godziny rocznie, podczas gdy średnia dla państw OECD to 1770 godzin, a w Niemczech jest to tylko 1371 godzin (dane za 2014 rok). Źródło: https:/ / stats.oecd.org/Index.aspx?DataSetCode=ANHRS\# [dostęp 21 marca 2016].

8 Por. np. K. Jaworski, Mission (im)possible. Pierwsze mieszkanie, „Obserwator Finansowy”, 1 lipca 2015, http://www.obserwatorfinansowy.pl/tematyka/makroekonomia/mission-impossible-pierwsze-mieszkanie/ [dostęp 21 marca 2016]. W artykule opisane sa zwiazane $z$ relatywnie niskimi zarobkami Polaków oraz z daleko niedoskonałymi rozwiąaniami prawnymi ogromne problemy Polaków ze zdobyciem mieszkania. W celu unaocznienia tego zjawiska autor przytacza między innymi wskaźnik przeludnienia mieszkań: „Dla Polski indeks ten wynosi $45 \%$, co pozwala nam na zajęcie „zaszczytnej” piątej (po Serbii, Rumunii, Macedonii i Węgrzech) najgorszej pozycji w Europie. Prawie połowa Polaków mieszka w lokalach niedostosowanych pod względem wielkości do ich sytuacji rodzinnej, podczas gdy w Unii Europejskiej (UE) to tylko $17 \%$ populacji, w strefie euro $12 \%$, a w Niemczech i Francji jedynie ok. 7-8\%". Przeludnienie to oznacza różne szkodliwe dla rodziny sytuacje: młodzi ludzie mieszkają $z$ rodzicami, gdyż nie maja możliwości zdobycia własnego mieszkania i przez to nie decyduja się na założenie rodziny; młode rodziny muszą mieszkać $z$ rodzicami jednego $z$ małżonków; mieszkanie jest zbyt małe w stosunku do liczby dzieci w rodzinie, co szkodzi komfortowemu rozwojowi dzieci.
} 